\title{
Perception of Health Effects of Environmental Pollutants Amongst Gas-Plant workers and Residents of Selected Local Government Areas of Delta State.
}

\author{
Arey Kingsley Eseoghene*, Okpako Johnson (Ph.D) \\ Department of Human Kinetics and Health Education, University of Port Harcourt. \\ *Corresponding Author:Arey Kingsley Eseoghene,Department of Human Kinetics and Health \\ Education, University of Port Harcourt.
}

\begin{abstract}
Although the Gas plant workplaces has been recognized as a priority setting for safety and health promotion activity because it is a high risk environment, yet not sufficient attention has been given to safety issues by stakeholders and management of oil and gas companies in Nigeria. The analytical descriptive survey design was adopted for this study from a population of 4,802,000 residents. A random sample of 1,300 respondent completed the questionnaire designed for the study, comprises Gas plant worker, high school teachers and resident of Gas plant communities. From six selected Local Government Area of Delta State using a 4point Likert scale model of SA,A,D,SD. Instrument for data collection was a researcher self designed questionnaire titled Environmental pollution on Health Impacts Questionnaire (EPOHIQ) which comprise of 56 test items which validated by three experts in safety and health education. The reliability of the instrument was validated using Pearson product moment correlation reliability and value of 0.78 was obtained. Data was analyzed using simple percentages and mean to answer two research questions at 0.05 alpha level of significance, while ANOVA was used to answer two research hypotheses.

Our findings shows that environmental pollutants is perceived to contribute to major health risks for gas plant workers and residents in Delta State. Further findings also revealed that environmental pollutants is perceived to affect the health conditions of gas plant workers and residents for the following prevalent diseases: malaria, diabetes, hypertension, asthma, cough, pneumonia, cholera, measles, several acute respiratory disease $(S A R D)$ and diarrhea.

Findings also reveal that there is gradual loss of manhours annually due to Lost Time Injury (LTI) among gas plant workers in the premises of Nigeria gas company, Warri. Further findings also reveal that there is a gradual annual reduction in productivity by gas plant workers due to Lost Time Injury (LTI) arising from high inhalation of environmental pollutants beyond safety limits set by Federal Ministry Environment. Recommendations is that management should urgently address the issue of declining productivity by engaging services of occupational health and safety consultants.

Findings reveals that there is an inverse relationship between knowledge of environmental pollutants and educational qualification by respondents.Further findings also reveals that there is a linear relationship between knowledge of environmental pollutants and social economic status attained by respondents. Implications of these findings for safety education were articulated in the write-up while recommendations for improved health promotion for heads of household on the use of greener friendly technology for cooking and lighting purposes in our homes.
\end{abstract}

Keywords:Workplace health promotion, perception, environmental pollutants, Lost Time Injury (LTI), Household health Promotion.

\section{INTRODUCTION}

Public perception of environmental pollutants by residents of gas bearing communities is a growing concern by stakeholders today. Through self reported actions for risky behaviours which aims to limit personal exposure to ambient air pollutants in our atmosphere, there is a growing realization amongst the public that drastic action must be taken to reduce the health effects of environmental pollutants to humans today.

Adverse health effects due to environmental pollutants for the public require accurate information to help develop a set of environmental solutions to perceived environmental health challenges in local 
communities. Public perception has been defined as the extent to which the public can identify specific environmental conditions that are caused by environmental pollutants and the coping mechanisms put in place to handle adverse health effect arising from them. (Bickerstauf, 2004)

The extent to which the public can identify specific environmental health conditions and contribute significantly as to whether they are able to cope with potential health risk from pollutants in our environment is a major concern of this study. Through face to face interaction and health promotion programmes a researcher can help determine the perception of residents to local environmental risks that is associated with pollutants and obtain the local environmental conditions by comparing public perception by residents of gas flaring communities with public health official surveillance records about environmental monitoring data so that a researcher can determine the accuracy of perception of residents of gas flaring communities.

The ability of the public to cope with adverse health outcomes due to primary environmental pollutants can be influenced by level of awareness about environmental pollutants in their immediate constituency, government and government agency quick response to pollution events and reaction of non-governmental agencies to pollution activities and the prevailing social and political milieu. (Slovic, 1993)

Several factors affect the public perception to environmental pollutants these includes; Gender, power, social economic status, political and economic privilege cultural bias, and religious affiliation.(Slovic, 1993).

External factors that can affect public perception include effectiveness of mass media coverage about pollution activity and events (Green Angle Programmes), communication with government and governmental agencies concern with pollution activities (Federal Ministry of Environmental, Federal Environmental Protection Agency, Department of Petroleum resources) and communication with experts on pollution events, then communication with non-governmental agencies dedicated to pollution events and activities. (Klisto, 2004).

The identification of specific environmental conditions caused by environmental pollutants has implications for quantifications and qualitation. There are two types of environmental pollutants occurring in nature today namely; primary environmental pollutant and secondary pollutants. The primary environmental pollutants are gaseous emissions produced from homes, factories, traffic vehicles, gas flaring sites and farm vegetation flaring sites. These emissions are otherwise called green house gases. There are twenty green house gases occurring in nature today which affects mankind today. These are; water vapour $\left(\mathrm{H}_{2} \mathrm{O}\right)$, Carbon-monoxide $(\mathrm{CO})$, Carbon-iv-oxide $\left(\mathrm{CO}_{2}\right)$, methane $\left(\mathrm{CH}_{4}\right)$ fluorinated gases-Hydrofluoro Carbon (HFC), Hydrochlorofluoro Carbon (HCFC), Chlorofluoro carbon (CFC) Perfluoro Carbon (PFC), Nitrogen Trifloride $\left(\mathrm{NF}_{3}\right)$, Sulphur Hexafluoride $\left(\mathrm{SHF}_{6}\right)$, Nitrous Oxide $\left(\mathrm{N}_{2} \mathrm{O}\right)$, Oxide of Sulphur $\left(\mathrm{SO}_{\mathbf{x}}\right)$, Carbon Sulphide (CS), Carbon Disulfide $\left(\mathrm{CS}_{2}\right)$, Volatile Organic Compounds $\left(\mathrm{VOC}_{\mathrm{S}}\right)-$ Benzene, $\left(\mathrm{C}_{6} \mathrm{H}_{6}\right)$, Benozopyrene, Toluene and heavy metals such as mercury $(\mathrm{Hg})$, Arsenic (As), Cadmium $(\mathrm{Cd})$ and Particulate matters $\left(\mathrm{PM}_{2.5}\right)($ Green House Emission Data, 2014).

Particulate matter is the most consistent and robust predictor of mortality from cardiovascular, pulmonary and other diseases in the study of long term exposure to air pollutants (Green House Emission Data, 2014).

Green House Effect is a phenomenon whereby the earth behaves as a heat blanket, when solar radiation from the sun enters the earth atmosphere as high level ultraviolet radiation. It is absorbed at the earth atmosphere and re-radiated back to space at high level energy infra red radiation. This trapped heat makes the average temperature of the earth to increase gradually, due to this gradual increase it result in climate change. (Green House Emission Data, 2014).

\section{Statement of the Problem}

The motivation for this study is based on three premises. Firstly reports from the scientific literature and personal observation of Gas Flaring Operations in Delta State.i. Gobo .A. E, Richard and Obong (2009) studies the health impacts of Gas Flaring Sites in Igwuruta/Umuechem Communities of Rivers State and found out that there is a marked and significant difference in the health status of residents of 
Gas Flaring Communities as compared to non-Gas Flaring Communities in Rivers State.

ii. Personal observation of Gas Flaring Operations in Utorogun Gas Plant in Udu Local Government Area of Delta State showed high periodic noise from gas plant sites and increased incidence of fire ball emissions from Gas Plant Sites. iii. Personal visit to the premises of Nigerian Gas company, Warri by the researcher.

Although preliminary studies from the gas plant communities gave promising result, much more research needs to be conducted to conclusively determine the health effects of Gas Flaring Emissions on gas plant workers and residents of Gas Flaring Communities in Delta State.

\section{AIM AND OBJECTIVES OF THE STUDY}

The aim and objective of the study is to determine the perception of health effects of environmental pollutants amongst gas plant workers/ residents of selected Local Government Areas of Delta State.

To achieve this aim, the following specific objectives will guide the study;

1. To determine the perception of health effect of environmental pollutant amongst gas plant workers/resident on their health status with respect to age, gender, marital status, socio-economic status, rank and educational qualification.

2. To establish the prevalent environmental pollutants among gas plant workers/residents of selectedlocal government areas in Delta State.

3. To establish the prevalent health condition due to environmental pollution among gas plant workers/resident of selected local government areas in Delta State.

\section{Research Questions}

1. What type of environmental pollutants do gas plant workers/ residents perceive to be prevalent amongst gas plant communities inDelta State.

2. What health condition do people perceive to be prevalent amongst gas plants workers/residents of host communities of Delta State.

3. What are the perceived health effects of environmental pollutants amongst gas plants workers/ residents of host communities with respect to age, gender, marital status, educational qualification, socio economic status and rank.

\section{Significance of the Study}

This study will be beneficial to the following persons, groups and stakeholders.

- Policy makers on safety and health in industry

- Reference guide to future researchers on occupational safety and health

- Reference guide to future researcherson household air pollution.

- Environmental health and safety professionals industry.

- Social environmentalrights and accountability projects (SERAP).

\section{Research Hypotheses}

1. There is no significant difference between the perception of health effects of environment pollutants amongst gas plant workers/residents of their host communities of Delta State.

2. There is no significant difference between the perception of health effects of environmental pollutants amongst gas plant workers/residents of Gas Flaring communities and non-Gas faring communities in Delta State with respect to Age, gender, marital status, educational qualification.

\section{METHOD}

The Analytical Descriptive survey design was adopted for this study. The population for the study comprise 4,802,490 residents (National Population Commission, 2012) . A random sample of 1300 workers/residents completed the questionnaire designed for the study. Multistage 
Perception of Health Effects of Environmental Pollutants Amongst Gas-Plant workers and Residents of Selected Local Government Areas of Delta State.

Samplingtechnique was used for the study. The first stage was the selecting six local; government area from the 25 local government areas in Delta State.The second stage was systematic drawing of a sample of 1300 workers/residents from the six selected local government area of Delta State namely Ughelli north, Ugheli south, Udu, Okpe, Uvwie and Ethiope East.

Instrument for data collection was researcher designed questionnaire titled environmental pollution on health impact questionnaire (EPOHIQ) which comprises of fifty six test items using a four point likert scale of SA, A, D and SD which was validated by three expert in safety and health promotion. The reliability of the instrument was validated using the test re-test method of reliability by using the pearson product moment reliability and a value of 0.78 was obtained.Instrument was administered by the researcher with the aid of two research assistants. Data was analyzed using simple percentages and mean to answer the research question at 0.05 alpha level of significance. The response options of SA, A, D and SD were assigned nominal values of 4, 3,2, 1 respectively. The respondents were asked to tick against the responses that best describe their point of view.

The retrieved questionnaire was collated and analyzed using SPSS (Statistical Package for Social Sciences version 21 batch system (IBM). A criterion mean of 2.5 and above were taken as significant and therefore regarded as adequate perception while mean score below 2.5 was taken as insignificant and therefore regarded as inadequate perception. The T-test statistic was used to test the null hypotheses at 0.05 level of significance at appropriate degrees of freedom.

Percentage response of the subjects on knowledge about environmental pollutants by gas plant workers/resident ofsix selected local government areasin Delta State.

\begin{tabular}{|c|c|c|c|}
\hline S/NO & & $\begin{array}{l}\text { TRUE } \\
\text { Frequency/Percentage }\end{array}$ & $\begin{array}{l}\text { FALSE } \\
\text { Frequency/Percentage }\end{array}$ \\
\hline 1. & $\begin{array}{l}\text { Carbon monoxide (CO): is a highly } \\
\text { poisonous gas which is produced from } \\
\text { incompleted combustion of fossil fuel } \\
\text { (wood, charcoal, natural gas, kerosene) }\end{array}$ & $\begin{array}{l}1130 \\
100 \%\end{array}$ & $\begin{array}{l}0 \\
0 \%\end{array}$ \\
\hline 2. & $\begin{array}{l}\text { Carbon dioxide }\left(\mathrm{CO}_{2}\right) \text { : is a colorless, } \\
\text { odorless and non-toxic greenhouse gas, } \\
\text { emitted from completed combustion of } \\
\text { fossil fuels (wood, charcoal, natural gas, } \\
\text { kerosene) }\end{array}$ & $\begin{array}{l}F=820 \\
72.6 \%\end{array}$ & $\begin{array}{l}\mathrm{F}=310 \\
27.4 \%\end{array}$ \\
\hline 3. & $\begin{array}{l}\text { Methane }\left(\mathrm{CH}_{4}\right): \text { is a greenhouse gas } \\
\text { produced as a gas that affects global } \\
\text { warming potential (GWP) which reduces } \\
\text { oxygen levels in the atmosphere. }\end{array}$ & $\begin{array}{l}F=1009 \\
89.3 \%\end{array}$ & $\begin{array}{l}\mathrm{F}=121 \\
10.7 \%\end{array}$ \\
\hline 4. & $\begin{array}{l}\text { Water Vapour }\left(\mathrm{H}_{2} \mathrm{O}\right) \text { : is a greenhouse gas } \\
\text { which absorbs long wave vibration and } \\
\text { contributes to global warming by trapping } \\
\text { heat in the atmosphere. }\end{array}$ & $\begin{array}{l}\mathrm{F}=1130 \\
100 \%\end{array}$ & $\begin{array}{l}F=0 \\
0 \%\end{array}$ \\
\hline 5. & $\begin{array}{l}\text { Hydrochlorocarbons (HCC); is a synthetic } \\
\text { and powerful greenhouse gas which when } \\
\text { inhaled at high level can be used as } \\
\text { substitutes for stratospheric ozone }\end{array}$ & $\begin{array}{l}F=1009 \\
100 \%\end{array}$ & $\begin{array}{l}\mathrm{F}=121 \\
10.7 \%\end{array}$ \\
\hline 6. & $\begin{array}{l}\text { Hydro chlorofluorocarbons (HCFC) is a } \\
\text { synthetic and powerful greenhouse gas that } \\
\text { causes climate change, which are emitted in } \\
\text { small quantities. }\end{array}$ & $\begin{array}{l}F=1130 \\
100 \%\end{array}$ & $\begin{array}{l}\mathrm{F}=121 \\
10.7 \%\end{array}$ \\
\hline 7. & $\begin{array}{l}\text { Perfluorocarbons (PFC): is a synthetic and } \\
\text { powerful greenhouse gas, produced from } \\
\text { industrial process that causes climate } \\
\text { change. }\end{array}$ & $\begin{array}{l}F=1009 \\
89.3 \%\end{array}$ & $\begin{array}{l}\mathrm{F}=121 \\
10.7 \%\end{array}$ \\
\hline 8. & $\begin{array}{l}\text { Nitrogen dioxide }\left(\mathrm{NO}_{2}\right) \text { : is a greenhouse gas } \\
\text { produced from gas automobile exhaust, gas } \\
\text { stoves, heaters. }\end{array}$ & $\begin{array}{l}\mathrm{F}=985 \\
87.2 \%\end{array}$ & $\begin{array}{l}\mathrm{F}=145 \\
12.8 \%\end{array}$ \\
\hline 9. & $\begin{array}{l}\text { Nitrogen triflouride }\left(\mathrm{NF}_{3}\right) \text { is a synthetic and } \\
\text { power greenhouse gas which cause global }\end{array}$ & $\begin{array}{l}F=864 \\
76.5 \%\end{array}$ & $\begin{array}{l}F=267 \\
23.5 \%\end{array}$ \\
\hline
\end{tabular}


Perception of Health Effects of Environmental Pollutants Amongst Gas-Plant workers and Residents of Selected Local Government Areas of Delta State.

\begin{tabular}{|c|c|c|c|}
\hline & warming & & \\
\hline 10 . & $\begin{array}{l}\text { Ozone }\left(\mathrm{O}_{3}\right) \text { : is a secondary pollutant found } \\
\text { in the atmosphere, produced by the reaction } \\
\text { between greenhouse gases and oxygen. }\end{array}$ & $\begin{array}{l}F=1008 \\
89.2 \%\end{array}$ & $\begin{array}{l}F=122 \\
10.8 \%\end{array}$ \\
\hline 11. & $\begin{array}{l}\text { Sulphur monoxide (SO): is produced from } \\
\text { exhaust of leaded fuel, react with air in the } \\
\text { atmosphere to produce } \mathrm{SO}_{2}\end{array}$ & $\begin{array}{l}F=1009 \\
89.3 \%\end{array}$ & $\begin{array}{l}F=121 \\
10.7 \%\end{array}$ \\
\hline 12. & $\begin{array}{l}\text { Sulphur dioxide }\left(\mathrm{SO}_{2}\right) \text { : is a colourless gas } \\
\text { with an unpleasant smell found in the } \\
\text { atmosphere }\end{array}$ & $\begin{array}{l}F=864 \\
76.5 \%\end{array}$ & $\begin{array}{l}F=266 \\
23.5 \%\end{array}$ \\
\hline 13. & $\begin{array}{l}\text { Nitrous Oxide (NO) is produced from } \\
\text { agricultural and industrial activities during } \\
\text { combustion of fuel, solid waste and during } \\
\text { treatment of waste water }\end{array}$ & $\begin{array}{l}F=985 \\
87.2 \%\end{array}$ & $\begin{array}{l}F=145 \\
12.8 \%\end{array}$ \\
\hline 14. & $\begin{array}{l}\text { Sulphur Hexafluoride }\left(\mathrm{SF}_{\mathbf{6}}\right) \text { is greenhouse } \\
\text { gas that is produced from the contribution of } \\
\text { gas flaring site treatment of waste water } \\
\text { from industrial processes }\end{array}$ & $\begin{array}{l}\mathrm{F}=985 \\
87.2 \%\end{array}$ & $\begin{array}{l}F=145 \\
12.8 \%\end{array}$ \\
\hline 15. & $\begin{array}{l}\text { Carbon Sulphide (CS) is a greenhouse gas } \\
\text { produced from exhaust of motor vehicles }\end{array}$ & $\begin{array}{l}F=522 \\
46.2 \%\end{array}$ & $\begin{array}{l}\mathrm{F}=608 \\
53.8 \%\end{array}$ \\
\hline 16. & $\begin{array}{l}\text { Carbon Sulphide (CS) is a greenhouse gas } \\
\text { also produced from exhaust of automobile } \\
\text { exhaust and gas stoves }\end{array}$ & $\begin{array}{l}\mathrm{F}=864 \\
76.5 \%\end{array}$ & $\begin{array}{l}F=266 \\
23.5 \%\end{array}$ \\
\hline 17. & $\begin{array}{l}\text { Benzene }\left(\mathrm{C}_{6} \mathrm{H}_{6}\right) \text { is a carcinogenic and toxic } \\
\text { greenhouse gas produced from gas flaring } \\
\text { sites }\end{array}$ & $\begin{array}{l}\text { F } 1130 \\
100 \%\end{array}$ & $\begin{array}{l}F=0 \\
0 \%\end{array}$ \\
\hline 18. & $\begin{array}{l}\text { Benzopryene }\left(\mathrm{C}_{6} \mathrm{H}_{6} \mathrm{O}\right) \text { is a carcinogenic and } \\
\text { toxic greenhouse gas produced from gas } \\
\text { flaring sites }\end{array}$ & $\begin{array}{l}F=1009 \\
89.3 \%\end{array}$ & $\begin{array}{l}F=121 \\
10.7 \%\end{array}$ \\
\hline 19. & $\begin{array}{l}\text { Toluene (To) is a carcinogenic and toxic } \\
\text { greenhouse gas which affect human health }\end{array}$ & $\begin{array}{l}F=1009 \\
89.3 \%\end{array}$ & $\begin{array}{l}\mathrm{F}=121 \\
10.7 \%\end{array}$ \\
\hline 20. & $\begin{array}{l}\text { Particulate Matter }\left(\mathrm{PM}_{2.5,10}\right) \text { is a greenhouse } \\
\text { gas that consist of tiny, solid and liquid } \\
\text { particles suspended in air. }\end{array}$ & $\begin{array}{l}F=820 \\
72.6 \%\end{array}$ & $\begin{array}{l}F=310 \\
27.4 \%\end{array}$ \\
\hline 21. & $\begin{array}{l}\text { Mercury (Hg) is a metallic greenhouse gas } \\
\text { suspended in the atmosphere that is } \\
\text { naturally occurring in the environment, } \\
\text { found in water, air and soil }\end{array}$ & $\begin{array}{l}F=985 \\
87.2 \%\end{array}$ & $\begin{array}{l}F=145 \\
12.8 \%\end{array}$ \\
\hline 22. & $\begin{array}{l}\text { Arsenic (As) is a greenhouse gas that is not } \\
\text { a metal but shares some metallic properties } \\
\text { with metals, hence called a metalloid. }\end{array}$ & $\begin{array}{l}\mathrm{F}=1130 \\
100 \%\end{array}$ & $\begin{array}{l}F=0 \\
0 \%\end{array}$ \\
\hline \multirow[t]{2}{*}{23.} & $\begin{array}{l}\text { Cadmium }(\mathrm{Cd}) \text { is a metallic greenhouse gas } \\
\text { that occurs naturally in the atmosphere that } \\
\text { affects human health }\end{array}$ & $\begin{array}{l}\mathrm{F}=1130 \\
100 \%\end{array}$ & $\begin{array}{l}F=0 \\
0 \%\end{array}$ \\
\hline & Overall total & $58.51 \%$ & $41.49 \%$ \\
\hline
\end{tabular}

Percentage response of health conditions due to environmental pollutants in six selected local government areas of Delta State.

\begin{tabular}{|l|l|l|l|}
\hline S/NO & \multicolumn{1}{|c|}{} & \multicolumn{1}{|c|}{ TRUE } & FALSE \\
\hline 1. & $\begin{array}{l}\text { Malaria is disease condition caused by infectious mosquito (Plasmodium) } \\
\text { which bits victim and causes headache's nausea, abdominal pain, profuse } \\
\text { sweating after a few weeks of infection }\end{array}$ & $\begin{array}{l}\mathrm{F}=1130 \\
100 \%\end{array}$ & $\begin{array}{l}\mathrm{F}=0 \\
0 \%\end{array}$ \\
\hline 2. & $\begin{array}{l}\text { Pneumonia is a disease condition, caused by a virus, symptoms include, } \\
\text { shallow breath, wheezing, dengue fever, loss of appetite, difficulty of } \\
\text { breathing and may include cough/chills }\end{array}$ & $\begin{array}{l}\mathrm{F}=1130 \\
100 \%\end{array}$ & $\begin{array}{l}\mathrm{F}=0 \\
0 \%\end{array}$ \\
\hline 3. & $\begin{array}{l}\text { Asthma is a disease condition caused by respiratory virus that result in } \\
\text { cold, flu, chest tightness, or pain, shortness of breath, coughing or } \\
\text { wheezing especially at night and during exercise }\end{array}$ & $\begin{array}{l}\mathrm{F}=1130 \\
100 \%\end{array}$ & $\begin{array}{l}\mathrm{F}=0 \\
0 \%\end{array}$ \\
\hline
\end{tabular}


Perception of Health Effects of Environmental Pollutants Amongst Gas-Plant workers and Residents of Selected Local Government Areas of Delta State.

\begin{tabular}{|l|l|l|l|}
\hline 4. & $\begin{array}{l}\text { Cough (pertussis) is a common medical condition in children and adults, } \\
\text { that affects the nose, throat and airways. Symptoms include, sneezing, } \\
\text { fatigue and decrease in exercise tolerance }\end{array}$ & $\begin{array}{l}\mathrm{F}=1130 \\
100 \%\end{array}$ & $\begin{array}{l}\mathrm{F}=0 \\
0 \%\end{array}$ \\
\hline 5. & $\begin{array}{l}\text { Diabetes is a chronic sickness that affects the was the body process blood } \\
\text { sugar (Glucose) }\end{array}$ & $\begin{array}{l}\mathrm{F}=1130 \\
100 \%\end{array}$ & $\begin{array}{l}\mathrm{F}=0 \\
0 \%\end{array}$ \\
\hline 6. & $\begin{array}{l}\text { Hypertension is a disease condition characterized by high blood pressure } \\
\text { in humans which might cause heart disease and stroke if not }\end{array}$ & $\begin{array}{l}\mathrm{F}=1130 \\
100 \%\end{array}$ & $\begin{array}{l}\mathrm{F}=0 \\
0 \%\end{array}$ \\
\hline 7. & $\begin{array}{l}\text { Diarrhea is a medical condition cause by salmonella bacteria in which } \\
\text { faeces are discharge from the bowels frequently in liquid form, symptoms } \\
\text { may include vomiting, irritable bowel syndrome or inflammatory bowel } \\
\text { diseases }\end{array}$ & $\begin{array}{l}\mathrm{F}=1130 \\
100 \%\end{array}$ & $\begin{array}{l}\mathrm{F}=0 \\
0 \%\end{array}$ \\
\hline 8. & $\begin{array}{l}\text { Cholera is an infectious disease of the small intestine caused by stains of } \\
\text { bacteria which can lead to dangerous fluid loss, vomiting, diarrhea, severe } \\
\text { dehydration and lower blood pressure }\end{array}$ & $\begin{array}{l}\mathrm{F}=1130 \\
100 \%\end{array}$ & $\begin{array}{l}\mathrm{F}=0 \\
0 \%\end{array}$ \\
\hline 9. & $\begin{array}{l}\text { Severe Acute Respiratory Disease (SARD) is a condition caused by a virus } \\
\text { (Corono virus) family causes common cold resulting in sneezing and } \\
\text { coughing. }\end{array}$ & $\begin{array}{l}\mathrm{F}=1130 \\
100 \%\end{array}$ & $\begin{array}{l}\mathrm{F}=0 \\
0 \%\end{array}$ \\
\hline 10. & $\begin{array}{l}\text { Measles is an infectious disease found especially in children, that causes } \\
\text { fever, sour throat and small red spots that covers the whole body and } \\
\text { occurs occasionally in adults (Mother) newborns }\end{array}$ & $\begin{array}{l}\mathrm{F}=1130 \\
100 \%\end{array}$ & $\begin{array}{l}\mathrm{F}=0 \\
0 \%\end{array}$ \\
\hline & Overall total & $\mathbf{1 0 0 \%}$ & $\mathbf{0 \%}$ \\
\hline
\end{tabular}

Percentage response of the subjects on knowledge about environmental pollutants by gas plant workers/ resident in six selected local government areas inDelta State.

\begin{tabular}{|c|c|c|c|c|c|}
\hline S/NO & & $\mathbf{S A}$ & $\mathbf{A}$ & $\mathbf{D}$ & SD \\
\hline 1. & $\begin{array}{l}\text { Carbon monoxide }(\mathrm{CO}) \text { : is a highly poisonous gas } \\
\text { which is produced from incompleted combustion of } \\
\text { fossil fuel (wood, charcoal, natural gas, kerosene) }\end{array}$ & $\begin{array}{l}\mathrm{F}=510 \\
45.1 \%\end{array}$ & $\begin{array}{l}\mathrm{F}=121 \\
10.7 \%\end{array}$ & $\begin{array}{l}\text { F 499 } \\
44.2 \%\end{array}$ & $\begin{array}{l}\mathrm{F}=0 \\
0 \%\end{array}$ \\
\hline 2. & $\begin{array}{l}\text { Carbon dioxide }\left(\mathrm{CO}_{2}\right) \text { : is a colorless, odorless and non- } \\
\text { toxic greenhouse gas, emitted from completed } \\
\text { combustion of fossil fuels (wood, charcoal, natural gas, } \\
\text { kerosene) }\end{array}$ & $\begin{array}{l}\mathrm{F}=310 \\
27.4 \%\end{array}$ & $\begin{array}{l}F=365 \\
32.3 \%\end{array}$ & $\begin{array}{l}\text { F 455 } \\
40.35\end{array}$ & $\begin{array}{l}\mathrm{F}=0 \\
0 \%\end{array}$ \\
\hline 3. & $\begin{array}{l}\text { Methane }\left(\mathrm{CH}_{4}\right) \text { : is a greenhouse gas produced as a gas } \\
\text { that affects global warming potential (GWP) which } \\
\text { reduces oxygen levels in the atmosphere. }\end{array}$ & $\begin{array}{l}\mathrm{F}=121 \\
10.7 \%\end{array}$ & $\begin{array}{l}F=257 \\
23.6 \%\end{array}$ & $\begin{array}{l}F=742 \\
67.7 \%\end{array}$ & $\begin{array}{l}\mathrm{F}=0 \\
0 \%\end{array}$ \\
\hline 4. & $\begin{array}{l}\text { Water Vapour }\left(\mathrm{H}_{2} \mathrm{O}\right) \text { : is a greenhouse gas which } \\
\text { absorbs long wave vibration and contributes to global } \\
\text { warming by trapping heat in the atmosphere. }\end{array}$ & $\begin{array}{l}\mathrm{F}=620 \\
54.9 \%\end{array}$ & $\begin{array}{l}\text { F 266 } \\
23.5 \%\end{array}$ & $\begin{array}{l}F=122 \\
10.8 \%\end{array}$ & $\begin{array}{l}F=122 \\
10.8 \%\end{array}$ \\
\hline 5. & $\begin{array}{l}\text { Hydrochlorocarbons (HCC); is a synthetic and } \\
\text { powerful greenhouse gas which when inhaled at high } \\
\text { level can be used as substitutes for stratospheric ozone }\end{array}$ & $\begin{array}{l}\mathrm{F}=620 \\
54.9 \%\end{array}$ & $\begin{array}{l}F=266 \\
23.5 \%\end{array}$ & $\begin{array}{l}F=122 \\
10.8 \%\end{array}$ & $\begin{array}{l}\mathrm{F}=122 \\
10.8 \%\end{array}$ \\
\hline 6. & $\begin{array}{l}\text { Hydro chlorofluorocarbons (HCFC) is a synthetic and } \\
\text { powerful greenhouse gas that causes climate change, } \\
\text { which are emitted in small quantities. }\end{array}$ & $\begin{array}{l}F=455 \\
40.3 \%\end{array}$ & $\begin{array}{l}\mathrm{F}=310 \\
27.4 \%\end{array}$ & $\begin{array}{l}F=365 \\
32.3 \%\end{array}$ & $\begin{array}{l}\mathrm{F}=0 \\
0 \%\end{array}$ \\
\hline 7. & $\begin{array}{l}\text { Perfluorocarbons (PFC): is a synthetic and powerful } \\
\text { greenhouse gas, produced from industrial process that } \\
\text { causes climate change. }\end{array}$ & $\begin{array}{l}F=455 \\
40.3 \%\end{array}$ & $\begin{array}{l}\mathrm{F}=286 \\
25.3 \%\end{array}$ & $\begin{array}{l}\mathrm{F}=389 \\
34.4 \%\end{array}$ & $\begin{array}{l}\mathrm{F}=0 \\
0 \%\end{array}$ \\
\hline 8. & $\begin{array}{l}\text { Nitrogen dioxide }\left(\mathrm{NO}_{2}\right) \text { : is a greenhouse gas produced } \\
\text { from gas automobile exhaust, gas stoves, heaters. }\end{array}$ & $\begin{array}{l}\mathrm{F}=455 \\
40.3 \%\end{array}$ & $\begin{array}{l}\mathrm{F}=122 \\
10.8 \%\end{array}$ & $\begin{array}{l}\mathrm{F}=553 \\
48.9 \%\end{array}$ & $\begin{array}{l}\mathrm{F}=0 \\
0 \%\end{array}$ \\
\hline 9. & $\begin{array}{l}\text { Nitrogen triflouride }\left(\mathrm{NF}_{3}\right) \text { is a synthetic and power } \\
\text { greenhouse gas which cause global warming }\end{array}$ & $\begin{array}{l}\mathrm{F}=576 \\
51 \%\end{array}$ & $\begin{array}{l}\mathrm{F}=122 \\
10.8 \%\end{array}$ & $\begin{array}{l}\mathrm{F}=122 \\
10.8 \%\end{array}$ & $\begin{array}{l}\mathrm{F}=310 \\
24.4 \%\end{array}$ \\
\hline$\overline{10 .}$ & $\begin{array}{l}\text { Ozone }\left(\mathrm{O}_{3}\right) \text { : is a secondary pollutant found in the } \\
\text { atmosphere, produced by the reaction between } \\
\text { greenhouse gases and oxygen. }\end{array}$ & $\begin{array}{l}\mathrm{F}=576 \\
51 \%\end{array}$ & $\begin{array}{l}\mathrm{F}=122 \\
10.8 \%\end{array}$ & $\begin{array}{l}\mathrm{F}=122 \\
10.8 \%\end{array}$ & $\begin{array}{l}\mathrm{F}=310 \\
24.4 \%\end{array}$ \\
\hline 11. & $\begin{array}{l}\text { Sulphur monoxide (SO): is produced from exhaust of } \\
\text { leaded fuel, react with air in the atmosphere to produce } \\
\mathrm{SO}_{2}\end{array}$ & $\begin{array}{l}\mathrm{F}=155 \\
22.6 \%\end{array}$ & $\begin{array}{l}\mathrm{F}=122 \\
10.8 \%\end{array}$ & $\begin{array}{l}\mathrm{F}=121 \\
10.7 \%\end{array}$ & $\begin{array}{l}\mathrm{F}=632 \\
55.9 \%\end{array}$ \\
\hline 12. & Sulphur dioxide $\left(\mathrm{SO}_{2}\right)$ : is a colourless gas with an & $\mathrm{F}=121$ & $\mathrm{~F}=1009$ & $\mathrm{~F}=0$ & $\mathrm{~F}=0$ \\
\hline
\end{tabular}


Perception of Health Effects of Environmental Pollutants Amongst Gas-Plant workers and Residents of Selected Local Government Areas of Delta State.

\begin{tabular}{|c|c|c|c|c|c|}
\hline & unpleasant smell found in the atmosphere & $10.7 \%$ & $89.3 \%$ & $0 \%$ & $0 \%$ \\
\hline 13. & $\begin{array}{l}\text { Nitrous Oxide (NO) is produced from agricultural and } \\
\text { industrial activities during combustion of fuel, solid } \\
\text { waste and during treatment of waste water }\end{array}$ & $\begin{array}{l}\mathrm{F}=256 \\
22.2 \%\end{array}$ & $\begin{array}{l}\mathrm{F}=388 \\
34.3 \%\end{array}$ & $\begin{array}{l}F=165 \\
14.6 \%\end{array}$ & $\begin{array}{l}\mathrm{F}=322 \\
28.8 \%\end{array}$ \\
\hline 14. & $\begin{array}{l}\text { Sulphur Hexafluoride }\left(\mathrm{SF}_{\mathbf{6}}\right) \text { is greenhouse gas that is } \\
\text { produced from the contribution of gas flaring site } \\
\text { treatment of waste water from industrial processes }\end{array}$ & $\begin{array}{l}\mathrm{F}=455 \\
40.3 \%\end{array}$ & $\begin{array}{l}F=122 \\
10.8 \%\end{array}$ & $\begin{array}{l}\mathrm{F}=553 \\
48.9 \%\end{array}$ & $\begin{array}{l}\mathrm{F}=0 \\
0 \%\end{array}$ \\
\hline 15. & $\begin{array}{l}\text { Carbon Sulphide (CS) is a greenhouse gas produced } \\
\text { from exhaust of motor vehicles }\end{array}$ & $\begin{array}{l}F=455 \\
40.3 \%\end{array}$ & $\begin{array}{l}\mathrm{F}=121 \\
10.7 \%\end{array}$ & $\begin{array}{l}\mathrm{F}=409 \\
36.2 \%\end{array}$ & $\begin{array}{l}\mathrm{F}=145 \\
12.8 \%\end{array}$ \\
\hline 16. & $\begin{array}{l}\text { Carbon Sulphide (CS) is a greenhouse gas also } \\
\text { produced from exhaust of automobile exhaust and gas } \\
\text { stoves }\end{array}$ & $\begin{array}{l}F=455 \\
40.3 \%\end{array}$ & $\begin{array}{l}\mathrm{F}=245 \\
21.5 \%\end{array}$ & $\begin{array}{l}F=145 \\
12.8 \%\end{array}$ & $\begin{array}{l}\mathrm{F}=287 \\
25.4 \%\end{array}$ \\
\hline 17. & $\begin{array}{l}\text { Benzene }\left(\mathrm{C}_{6} \mathrm{H}_{6}\right) \text { is a carcinogenic and toxic greenhouse } \\
\text { gas produced from gas flaring sites }\end{array}$ & $\begin{array}{l}F=455 \\
40.3 \%\end{array}$ & $\begin{array}{l}\mathrm{F}=530 \\
46.9 \%\end{array}$ & $\begin{array}{l}F=145 \\
12.8 \%\end{array}$ & $\begin{array}{l}\mathrm{F}=0 \\
0 \%\end{array}$ \\
\hline 18. & $\begin{array}{l}\text { Benzopryene }\left(\mathrm{C}_{6} \mathrm{H}_{6} \mathrm{O}\right) \text { is a carcinogenic and toxic } \\
\text { greenhouse gas produced from gas flaring sites }\end{array}$ & $\begin{array}{l}\mathrm{F}=455 \\
40.3 \%\end{array}$ & $\begin{array}{l}\mathrm{F}=388 \\
34.3 \%\end{array}$ & $\begin{array}{l}\mathrm{F}=287 \\
25.4 \%\end{array}$ & $\begin{array}{l}\mathrm{F}=0 \\
0 \%\end{array}$ \\
\hline 19. & $\begin{array}{l}\text { Toluene (To) is a carcinogenic and toxic greenhouse } \\
\text { gas which affect human health }\end{array}$ & $\begin{array}{l}\mathrm{F}=455 \\
40.3 \%\end{array}$ & $\begin{array}{l}\mathrm{F}=267 \\
23.6 \%\end{array}$ & $\begin{array}{l}\mathrm{F}=121 \\
10.7 \%\end{array}$ & $\begin{array}{l}\mathrm{F}=287 \\
25.4 \%\end{array}$ \\
\hline 20. & $\begin{array}{l}\text { Particulate Matter }\left(\mathrm{PM}_{2.5,10}\right) \text { is a greenhouse gas that } \\
\text { consist of tiny, solid and liquid particles suspended in } \\
\text { air. }\end{array}$ & $\begin{array}{l}F=455 \\
40.3 \%\end{array}$ & $\begin{array}{l}\mathrm{F}=431 \\
38.1 \%\end{array}$ & $\begin{array}{l}F=122 \\
10.8 \%\end{array}$ & $\begin{array}{l}F=122 \\
10.8 \%\end{array}$ \\
\hline 21. & $\begin{array}{l}\text { Mercury }(\mathrm{Hg}) \text { is a metallic greenhouse gas suspended } \\
\text { in the atmosphere that is naturally occurring in the } \\
\text { environment, found in water, air and soil }\end{array}$ & $\begin{array}{l}\mathrm{F}=676 \\
51 \%\end{array}$ & $\begin{array}{l}\mathrm{F}=122 \\
10.8 \%\end{array}$ & $\begin{array}{l}\mathrm{F}=310 \\
27.4 \%\end{array}$ & $\begin{array}{l}F=122 \\
10.8 \%\end{array}$ \\
\hline 22. & $\begin{array}{l}\text { Arsenic (As) is a greenhouse gas that is not a metal but } \\
\text { shares some metallic properties with metals, hence } \\
\text { called a metalloid. }\end{array}$ & $\begin{array}{l}\mathrm{F}=442 \\
31.1 \%\end{array}$ & $\begin{array}{l}\mathrm{F}=122 \\
10.8 \%\end{array}$ & $\begin{array}{l}F=267 \\
23.6 \%\end{array}$ & $\begin{array}{l}F=299 \\
26.5 \%\end{array}$ \\
\hline 23. & $\begin{array}{l}\text { Cadmium }(\mathrm{Cd}) \text { is a metallic greenhouse gas that occurs } \\
\text { naturally in the atmosphere that affects human health }\end{array}$ & $\begin{array}{l}\mathrm{F}=442 \\
31.1 \%\end{array}$ & $\begin{array}{l}F=122 \\
10.8 \%\end{array}$ & $\begin{array}{l}F=267 \\
23.6 \%\end{array}$ & $\begin{array}{l}\mathrm{F}=299 \\
26.5 \%\end{array}$ \\
\hline & Overall total & $60.8 \%$ & $39.2 \%$ & $69.45 \%$ & $0.57 \%$ \\
\hline
\end{tabular}

\section{Research Hypotheses}

Hypothesis 1: There is no significant difference between the perception of physical health effects of environmental pollutants amongst Gas Plant workers/residents of selected local government areas with respect to age.

Hypothesis 1 was tested using analysis of variance (ANOVA) and results has been shown in the table below.

\begin{tabular}{|l|l|l|l|l|l|}
\hline & Sum of Square & df & Mean Square & f & Sig \\
\hline $\begin{array}{l}\text { Between } \\
\text { groups }\end{array}$ & 30.372 & 2 & 15.186 & 41.442 & 0.00 \\
\hline $\begin{array}{l}\text { Within } \\
\text { groups }\end{array}$ & 412.983 & 1127 & 0.366 & & \\
\hline Total & $\mathbf{4 4 3 . 3 5 8}$ & $\mathbf{1 1 2 9}$ & & & \\
\hline
\end{tabular}

The table above shows the mean square between groups and the mean square within groups which are 15.186 and 0.366 respectively. The degrees of freedom between groups, within groups and total are 2,1127 and 1129 respectively. The calculated $\mathrm{f}$ value of 41.442 which is significant at 0.00 alpha level. Since 0.00 alpha level is less than 0.05 alpha level, the calculated $f$ value is also significant at 0.05 alpha level. Since the calculated $f$ value is significant at 0.05 alpha level, the null hypothesis was rejected while the alternate hypothesis was accepted. This implies that there is significant difference in the perception of physical health effects of environmental pollutants amongst gas plant residents of Okpe/Uvwie Communities with respect to age.

Hypothesis 2: There is no significant difference between the perception of physical health effects of environmental pollutants amongst Gas Plant workers/residents in selected local government areas with respect to educational qualification. 
Perception of Health Effects of Environmental Pollutants Amongst Gas-Plant workers and Residents of Selected Local Government Areas of Delta State.

Hypothesis 2 was tested usinganalysis of variance (ANOVA) and results has been shown in the table below.

\begin{tabular}{|l|l|l|l|l|l|}
\hline & Sum of Square & Df & Mean Square & f & Sig \\
\hline $\begin{array}{l}\text { Between } \\
\text { groups }\end{array}$ & 4.172 & 1 & 4.172 & 10.715 & 0.001 \\
\hline $\begin{array}{l}\text { Within } \\
\text { groups }\end{array}$ & 439.184 & 1128 & 389 & & \\
\hline Total & $\mathbf{4 4 3 . 3 5 8}$ & $\mathbf{1 1 2 9}$ & & & \\
\hline
\end{tabular}

The table above show the mean square between groups and the mean square within groups which are 4.172 and 439.184 respectively. The degrees of freedom between groups, within groups and total are 1 and 1128 respectively. The calculated $\mathrm{f}$ value is 10.715 which is significant at 0.001 alpha level. Since 0.001 alpha level is less than 0.05 alpha level, the calculated $\mathrm{f}$ value is also significant at 0.05 alpha level. Since the calculated $\mathrm{f}$ value is also significant at 0.05 alpha level. Since the calculated $\mathrm{f}$ value is significant at 0.05 alpha, the null hypothesis was rejected while the alternate hypothesis was accepted. This implies that there is significant difference in the perception of physical health effects of environmental pollutants amongst gas plant workers/residents of selected local government areas with respect to educational qualification.

\section{DISCUSSION}

The study aimed at determining the perception of health effects of environmental pollutants by gas plant workers/residents of selected Local Government Area of Delta State.

Major findings of the studies are:

i. Residents of six selected local government areas showed adequate knowledge of health conditions caused by environmental pollutants in Delta State.

ii. Residents of six selected local government areas showed some knowledge of environmental pollutants affecting residents of Gas Flaring Communities.

iii. Residents of Urban selected Local Government Area showed a higher perception of knowledge of health effects of environmental pollutants as compared to residents of rural selected Local Government Areas.

iv. The researcher also find an inverse relationship between perception of environmental pollutants and level of education attained by gas plant workers/residents of both communities.

v. Majority of residents of both communities perceived the physical health effects of environmental pollutants.

vi. Majority of gas plant workers/residents in both communities observed that thirteen environmental pollutants were perceived to be prevalent amongst residents of host communities.

vii. There is a linear relationship between perception of health effects of environmental pollutants by gas plant workers/residents and social economic status.

viii. Age and gender have significant effect on perception of environmental pollutants on health by gas plant workers/residents of Gas Flaring communities of Delta State.

ix. Residents of Gas Plant communities have not received adequate knowledge of effects of environmental pollutants on health that can enable them to cope with health risk ravaging their communities.

x. Residents of six selected Local Government Areas need to improve on personal hygiene and sanitation so as to improve their health status.

Ajala andBolarinwa (2002) established that men tend to perceive more environmental health issues than their female counterparts. This finding agrees with the results of this present study. Norekel (1992) and Adeogun, Idowu (2002) observed that experience and behaviour constitute an important principle in perception. This implies that perception is expected to change with time. 
Perception of Health Effects of Environmental Pollutants Amongst Gas-Plant workers and Residents of Selected Local Government Areas of Delta State.

\section{IMPLICATIONS OF THE STUDY}

In order to determine accurately the perception of gas plant workers/residents to local environmental health conditions in six selected local government areas that is associated with environmental pollutants we obtained the local environmental health conditions by comparing public perception by residents of Gas Flaring Communities with public health official surveillance records from Primary Health Care Centres in Delta State titled Integrated Data Surveillance Records (IDSR) form 003 provided by World Health Organization which was collected from disease surveillance officers in each Local Government Areas for the period (2016-2019) and compared same with the public perception of residents in six selected Local Government Areas. The table below shows the comparison of health effects of environmental pollutants as reported from the disease surveillance records for two local government areas namelyOkpe/Uvwie Local Government Areas respectively.

Table showing prevalence of health conditions for residents of two selected local government areas namely Okpe/Uvwie Communities in Delta State

\begin{tabular}{|l|l|l|l|l|l|}
\hline S/NO & & $\begin{array}{l}\text { OKPE } \\
\mathbf{2 0 1 8}\end{array}$ & $\begin{array}{l}\text { UVWIE } \\
\mathbf{2 0 1 8}\end{array}$ & $\begin{array}{l}\text { OKPE } \\
\mathbf{2 0 1 9}\end{array}$ & $\begin{array}{l}\text { UVWIE } \\
\mathbf{2 0 1 9}\end{array}$ \\
\hline i. & Malaria & 12,018 & $\begin{array}{l}18,040 \\
1.50\end{array}$ & 11,577 & $\begin{array}{l}37,486 \\
3.23\end{array}$ \\
\hline ii. & Pneumonia & 00 & 63 & 00 & 32 \\
\hline ii. & Asthma & 98 & 375 & 20 & 1015 \\
& & & 3.85 & & 50.75 \\
\hline iv. & Cough (Pertussis) & 00 & 00 & 00 & 95 \\
\hline v. & Diabetes & 121 & 1018 & 19 & 1881 \\
\hline vi. & Hypertension & & 8.4 & & 99 \\
\hline iii. & Diarrhea & 259 & 2214 & 143 & 3072 \\
& & & 8.5 & & 21.4 \\
\hline iii. & Cholera & 24 & 615 & 19 & 851 \\
\hline ix. & Severe Acute Respiratory Disease (SARD) & 00 & 00 & 00 & 00 \\
\hline x. & Measles & & 126 & 173 & 2840 \\
& & 00 & 24 & 07 & 64 \\
\hline
\end{tabular}

Source: Integrated disease surveillance reports form 003 (for Okpe and Uvwie Local Government Area of Delta State).

The result also confirmed that the health effects of environmental pollutants is higher among residents of Urban Local Government Area as compared to rural Local Government Area. The result from the disease surveillance office shows that out of twenty-three health effects of health conditions provided by World Health Organization (WHO) survey proformafor incident and prevalent health conditions. Ten health conditions were found to be prevalent due to the effects of environmental pollutants on the health status of residents ofthe six Local Government Areas investigated by the researcher.

The identified ten prevalent health conditions are; malaria, diabetes, cholera, pneumonia, measles, cough, severe Acute Respiratory Disease (ARD), hypertension, asthma and diarrhea.

\section{CONCLUSION}

To avert the health impact of environmental pollutants on gas plant workers/residents of six selected Local Government Area of Delta State, gas plant workers/residents needs to embrace cleaner, cost effective and greener technology for cooking and boiling purposes at home.

It was also found that there is a linear quadratic relationship between perception of health effects for environmental pollutants by residents of Okpe/UvwieLocal Government Areas with respect to age and social economic status. 


\section{RECOMMENDATIONS}

i. The wearing of gas mask respirators and nose muffs should be worn by all gas plant workers within the premise of the gas plant to reduce the effect of inhalation of environmental pollutants beyond prescribed health and safety limits (Ministry of Environment).

ii. A safety committee should be constituted by management of Nigerian Gas Company to ensure compliance and enforcement of wearing of personal protective equipment with specific reference to Gas mask respirators and nose muffs within the premises of the gas plants.

iii. The management of Nigeria Gas Company should make enough budgetary provision for a purchase of personal protective equipment-gas mask respirators and nose muffs for all workers in the gas plant premises to reduce exposure to environmental pollutants.

iv. The researcher hereby also calls for a legislation National Assembly which mandates management of all oil and gas companies in Nigeria to prescribe the wearing of gas mask respirators and nose muffs by all gas plant workers and within the premises of the gas plant and during working hours only.

v. The minister for environment should urgently constitute the national council for occupational health and safety to prescribe and maintain minimum standard for environmental safety and health activities in the industry.

vi. The minister for environment should setup an expert committee to review the environmental guidelines and standard for safety act for operators the oil and gas industry in Nigeria (EGASPIN act, 2004). So that it can be update to reflect current environmental safety benchmarks (limits) in the industry.

vii. Government and non-governmental agencies should make more budgetary allocation to household safety and health promotion programmes to urgently increase awareness on environmental pollutants in our homes.

viii. While building engineers and local health authorities in the twenty five Local Government Areas in Delta State should inspect prospective new houses for installation of modern chimney in houses before granting them building permit to reduce the incidence of green house pollution in our homes.

ix. Household air pollution reduction bill 2020. Researcher hereby propose for a bill to be enacted by the Delta State of house of Assembly to reduce incidence of greenhouse household air pollutions in our homes.

x. Heads of household and their spouses should be encouraged to adopt greener, cleaner and cost effective technology for cooking and boiling purposes through safety and health promotion activities initiated by Non-Governmental Organizations (NGO).

\section{REFERENCES}

[1] Achalu E. I. (1997) The Need to Promote the Health of the Nigeria Worker.Nigeria School Health Journal Vol. 9:16.

[2] Achalu E. I. (1989) Injury Control In Perceptive. America Journal of Public Health Vol. 14:234

[3] Achalu E. I. and Okpako (2018) Knowledge of Oral Health Among Pension in Port Harcourt Metropolis, Rivers State.

[4] Afiuemueku F. (2004) Occupation and Safety: Issues And Perspectives Selected Writings.Journal of Public Health Vol. 14:234

[5] Dioha M. O. (2014) Modeling the Impact of Nigeria Household Energy Policy on Energy Consumption and $\mathrm{Co}_{2}$ Emission.Journal of Environment Energy and Natural Research Vol. 22:114-128

[6] Daniels M. E. and Donlon T. E. (2014) the Emerging Global Health Crisis: Non Communicable Disease Attributable to Ambient Air Pollution: An Analysis of Data From the Global Burden of Disease Study (2015) Lancet 389:1907-1918.

[7] Global Burden of Disease (2018) From Major Air Pollution Sources (Maps).Reports on China and India (HED) for World Health Organization.Geneva Switzerland. 
Perception of Health Effects of Environmental Pollutants Amongst Gas-Plant workers and Residents of Selected Local Government Areas of Delta State.

[8] Green L. W, Kreabe M. O. (1974) Health Promotion Planning: An Educational and Commercial Approach. Mountain View California May Field Publishing USA.

[9] Green J. (2000) Editorial: The Role of Theory in Evidence Based Health Promotion Practice. Health Education Research Vol: 16:128-129

[10] Health Effects Institute (2018) State of Global Air. Special Report, Boston Massachusetts USA. Health Effect Institute.

[11] Health Effects Institute (In Press) Air Pollution And Non-Communicable Disease. Communication 18 Boston Massachusetts USA. Health Effect Institute.

[12] International Agency for Research in Cancer (2013).Air pollution and cancer.JARC Scientific Publication no161 LYON France.World Health Organization.

[13] International Resource Panel (2015).The International Resource Panel. 10 key messages on climate change. World Health Organization.

[14] Institute for Health Metrics and Evaluation (2018). Global Research Centre.Risk Factors Contributing to Health Strategy Paper. University Of Washington USA.

[15] Orunaboka T. (2015) A Test Book on Research Methods for Graduate Students for Schools And Colleges. Uniport University Press, Port Harcourt.

[16] WHO (2016) Guidelines for Indoor Air Quality Household Fuel Combustion.Executive Summary Report.Geneva Switzerland.

[17] WHO (2016) Burning Opportunity for Clean Household Energy for Health. Sustainable Development Goals and Wellbeing of Women and Children.Geneva Switzerland.

Citation: Arey Kingsley Eseoghene\&Okpako Johnson (Ph.D). "Perception of Health Effects of Environmental Pollutants Amongst Gas-Plant workers and Residents of Selected Local Government Areas of Delta State." International Journal of Humanities Social Sciences and Education (IJHSSE), vol 7, no. 4, 2020, pp. 118-128. doi: http://dx.doi.org/10.20431/2349-0381.0704012.

Copyright: (C) 2020 Authors. This is an open-access article distributed under the terms of the Creative Commons Attribution License, which permits unrestricted use, distribution, and reproduction in any medium, provided the original author and source are credited. 